\title{
Complete Genome of Xanthomonas arboricola pv. corylina Strain A7 Isolated from Southern Chile
}

\author{
Pablo Núñez, ${ }^{1, \dagger}$ Cecilia Muster, ${ }^{2}$ María José Lisperguer, ${ }^{3}$ Ester Vargas, ${ }^{2}$ and Sofia Bustos ${ }^{2}$ \\ ${ }^{1}$ Laboratorio AgroScreening SpA, Avenida Larraín 5862, Piso 12, La Reina, Chile \\ ${ }^{2}$ Agroadvance SpA, Camino a Melipilla 26200, Peñaflor, Chile \\ ${ }^{3}$ Frutícola Agrichile S.A. Hijuela 1, Los Niches, Curicó, Chile
}

\section{Abstract}

The complete genome sequence of Xanthomonas arboricola pv. corylina A7 was obtained by a hybrid approach combining PacBio and Illumina HiSeq sequence data. A single circular chromosome of $5.1 \mathrm{mb}$ with $65.47 \% \mathrm{G}+\mathrm{C}$ content was obtained, including 4,344 coding sequences identified as well as some genes involved in copper resistance. The information obtained corresponds to the first report of a high-quality whole genome of $X$. arboricola pv. corylina, isolated from infected hazelnut trees in southern Chile.

\section{Genome Announcement}

Chile is the largest hazelnut producer in the Southern Hemisphere and this cultivation covers more than 20,000 hectares (Ellena et al. 2014; Guerrero Contreras et al. 2020). One important loss of productivity of hazelnut cultivation is due to the disease caused by $X$. arboricola pv. corylina (Ellena et al. 2014). Disease control conventionally involves the application of copper compounds, three to four sprays per year (Ellena et al. 2014), whose use in Chile has been shown to be related to copper resistance acquisition in X. arboricola pv. corylina isolates (Chavez and Durán 2020).

This announcement describes the whole genome of $X$. arboricola pv. corylina strain A7 isolated from infected hazelnut trees with a potential of copper resistance. $X$. arboricola pv. corylina A7 was selected from 12 strains isolated from hazelnut trees with characteristic symptoms of bacterial blight from Camarico, Región del Maule, Chile (Lamichhane and Varvaro 2014). This site has been consistently managed with copper (II) hydroxide and copper (II) sulfate pentahydrate to treat bacterial blight considering two applications per season, in leaf fall and at the beginning of sprouting. The bacterial isolate was selected for its capacity for growing in vitro with high copper concentration (130 $\mu \mathrm{g}$ of $\mathrm{Cu}^{2+}$ per milliliter) (Moya-Elizondo et al. 2018).

$X$. arboricola pv. corylina A7 was grown in YPG medium (10 $\mathrm{g}$ of peptone, $5 \mathrm{~g}$ of yeast extract, and $5 \mathrm{~g}$ of glucose per liter [Difco]) for $48 \mathrm{~h}$. Genomic DNA was isolated using a QIAamp DNA mini kit (Qiagen), following manufacturer protocols. DNA sequencing was performed on an Illumina HiSeq 4000 platform, using a TruSeq DNA 350-bp library with a $2 \times$ $100 \mathrm{bp}$ paired-end protocol (Macrogen). A total of 11,206,268 reads were obtained. Read quality was checked using FastQC (Andrews 2010), and low-quality sequences were trimmed, using Trim Galore (Krueger 2016). For long-read sequencing, a 20-kb SMRTbell library was prepared and was sequenced on the PacBio platform (Macrogen). In all, 55,637 raw PacBio reads were longer than $18,317 \mathrm{bp}$.

${ }^{\dagger}$ Corresponding author: P. Núñez; pnunez@agroscreening.cl

The author(s) declare no conflict of interest.

Accepted for publication 29 May 2021.

(c) (i) $($ ) $\odot$ Copyright (C 2021 The Author(s). This is an open access article distributed under the CC BY-NC-ND 4.0 (c)
Funding

Support was provided by Corporación de Fomento de la Producción (Corporation for Economic Development Agency) grant number 19 CYE123908.

Keywords

bacterial blight, hazelnut, whole genome 
Genome assembly was performed using hybrid assembler Unicycler (Wick et al. 2017) with default parameters for hybrid assembly. One circular chromosome of 5,166,498 bp (65.47\% G/C content) was obtained, with a coverage over $500 \times$. The chromosome was visualized with Geneious Prime 2020 1.2.

The assembled genome was annotated using the National Center for Biotechnology Information (NCBI) Prokaryotic Genome Annotation Pipeline (Tatusova et al. 2016). A total of 4,344 coding sequences, 160 pseudogenes, two complete ribosomal RNA operons (each operon containing 5S, 16S, 23S), 54 transfer RNAs, and 36 noncoding RNAs were predicted by this pipeline.

Regarding copper resistance genes, the operon $\operatorname{cop} A B, \operatorname{cop} L$, cutC, and a PCuAC protein-encoding gene were found in the genome annotation. In the Xanthomonas axonopodis pv. citri genome, copAB gene products may play an important role in the copperresistance mechanism and $\operatorname{cop} L$ could regulate the $\operatorname{cop} A B$ operon (Teixeira et al. 2008). It has also been found that copper homeostasis protein CutC (cutC) and copper chaperone PCuAC could be implicated in the survival of $X$. arboricola pv. corylina in a high concentration of copper (Latorre et al. 2011; Thompson et al. 2013).

Identification of the copAB operon and copL, cutC, and PCuAC genes in the genome suggests the inefficacy of copper-based compounds for the treatment of Xanthomona arboricola pv. corylina A7 in hazelnut. To our knowledge, this is the first report of the whole genome of $X$. arboricola pv. corylina isolate in productive hazelnut crops in southern Chile and it complements the information described by lbarra Caballero et al. (2013), providing a valuable resource for future studies.

\section{Data Availability}

The draft assembly of the $X$. arboricola pv. corylina strain A7 has been deposited in the NCBI GenBank database under accession number CP062164. Raw Illumina HiSeq reads and PacBio reads have been deposited in NCBI Short Read Archive under BioProject accession number PRJNA661460, SRR12693513/SRR12693512.

\section{Author-Recommended Internet Resource}

Geneious Prime 2020 1.2: https://www.geneious.com

\section{Literature Cited}

Andrews, S. 2010. FastQC: A quality control tool for high throughput sequence data. Brabraham Informatics, Babraham Institute, Cambridge. https://www. bioinformatics.babraham.ac.uk/projects/fastqc/

Chavez, M., and Durán, P. 2020. Tizón del avellano: Desarrollo de un Sistema de alerta temprana. Red Agrícola.

Ellena, M., Sandoval, P., Gonzalez, A., Jequier, J., Contreras, M., and Beretta, P. G. 2014. Chilean hazelnut situation and perspectives. Acta Hortic. 1052: 339-342.

Guerrero Contreras, J., Galdamez Gutierrez, R., Ogass Contreras, K., and Pérez Fuentealba, S. 2020. First report of Diaporthe foeniculina causing black tip and necrotic spot on hazelnut kernel in Chile. Plant Dis. 104: 975.

Ibarra Caballero, J., Zerillo, M. M., Snelling, J., Boucher, C., and Tisserat, N. 2013. Genome sequence of Xanthomonas arboricola pv. Corylina, isolated from Turkish Filbert in Colorado. Genome Announc. 1:e00246-e13.

Krueger, F. 2016. Trim Galore! Brabraham Informatics, Babraham Institute, Cambridge. https://www.bioinformatics.babraham.ac.uk/projects/trim_galore/

Lamichhane, J. R., and Varvaro, L. 2014. Xanthomonas arboricola disease of hazelnut: Current status and future perspectives for its management. Plant Pathol. 63:243-254.
Latorre, M., Olivares, F., Reyes-Jara, A., López, G., and González, M. 2011. CutC is induced late during copper exposure and can modify intracellular copper content in Enterococcus faecalis. Biochem. Biophys. Res. Commun. 406:633-637.

Moya-Elizondo, E., Auil, P., Oyarzúa, P., and Gerding G, M. 2018. Resistance of Xanthomonas arboricola pv. juglandis to ion copper in walnut orchards in the BioBio region. Chil. J. Agric. Anim. Sci. 34:1-9.

Tatusova, T., DiCuccio, M., Badretdin, A., Chetvernin, V., Nawrocki, E. P., Zaslavsky, L., Lomsadze, A., Pruitt, K. D., Borodovsky, M., and Ostell, J. 2016. NCBI prokaryotic genome annotation pipeline. Nucleic Acids Res. 44:6614-6624.

Teixeira, E. C., Franco de Oliveira, J. C., Marques Novo, M. T., and Bertolini, M. C. 2008. The copper resistance operon copAB from Xanthomonas axonopodis pathovar citri: Gene inactivation results in copper sensitivity. Microbiology 154:402-412.

Thompson, A., Gray, J., Liu, A., and Holser, J. 2013. The roles of Rhodobacter sphaeroides copper chaperones PCuA C and Sco (PrrC) in the assembly of the copper centers of the aa3-type and the cbb3-type cytochrome $c$ oxidases. Biochim. Biophys. Acta Bioenerg. 1817:955-964.

Wick, R. R., Judd, L. M., Gorrie, C. L., and Holt, K. E. 2017. Unicycler: Resolving bacterial genome assemblies from short and long sequencing reads. PLOS Comput. Biol. 13:e1005595. 